\title{
Roles of Rapsyn and Agrin in Interaction of Postsynaptic Proteins with Acetylcholine Receptors
}

\author{
Christian Fuhrer, ${ }^{1}$ Medha Gautam, ${ }^{2}$ Janice E. Sugiyama, ${ }^{1}$ and Zach W. Hall ${ }^{1}$ \\ 'Section on Synaptic Mechanisms, Laboratory of Cellular and Molecular Regulation, National Institute of Mental Health, \\ National Institutes of Health, Bethesda, Maryland 20892, and 2Department of Molecular Biology and Pharmacology, \\ Washington University Medical School, St. Louis, Missouri 63110
}

At the neuromuscular junction, aggregates of acetylcholine receptors (AChRs) are anchored in the muscle membrane by association with rapsyn and other postsynaptic proteins. We have investigated the interactions between the AChR and these proteins in cultured C2 myotubes before and after treatment with agrin, a nerve-derived protein that induces AChRs to cluster. When AChRs were isolated from detergent extracts of untreated $\mathrm{C} 2$ myotubes, they were associated with rapsyn and, to a lesser degree, with utrophin, $\beta$-dystroglycan, MuSK, and src-related kinases, but not with syntrophin. Treatment with agrin increased the association of AChRs with MuSK, a receptor tyrosine kinase that forms part of the agrin receptor complex, without affecting other interactions. Analysis of rapsyndeficient myotubes, which do not form protein clusters in response to agrin, revealed that rapsyn is required for association of the AChR with utrophin and $\beta$-dystroglycan, and for the agrin-induced increase in association with MuSK, but not for constitutive interactions with MuSK and src-related kinases. In rapsyn -/- myotubes, agrin caused normal tyrosine phosphorylation of AChR-associated and total MuSK, whereas phosphorylation of the AChR $\beta$ subunit, both constitutive and agrininduced, was strongly reduced. These results show first that aneural myotubes contain preassembled AChR protein complexes that may function in the assembly of the postsynaptic apparatus, and second that rapsyn, in addition to its role in AChR phosphorylation, mediates selected protein interactions with the AChR and serves as a link between the AChR and the dystrophin/utrophin glycoprotein complex.

Key words: synaptogenesis; acetylcholine receptor; agrin; rapsyn; neuromuscular junction; tyrosine phosphorylation; protein interactions
The accumulation of acetylcholine receptors (AChRs) is a characteristic feature of the postsynaptic membrane at the neuromuscular junction and is believed to arise through interactions with the cytoskeleton (Froehner, 1991; Hall and Sanes, 1993). Little information is available, however, about the interactions of the AChR with other muscle proteins and how they change during development (Colledge and Froehner, 1998a).

The specialized postsynaptic membrane is formed through the action of agrin, a neurally released protein necessary for synapse formation in vivo (McMahan, 1990; Gautam et al., 1996). When added to cultured myotubes in vitro or supplied by injected myofibers in vivo, agrin also causes aggregation of AChRs, acetylcholinesterase, and other synaptic proteins (Wallace, 1989; Ferns et al., 1992; Reist et al., 1992; Cohen et al., 1997; Meier et al., 1997).

Little is known about the signaling pathway of agrin, but the receptor tyrosine kinase MuSK (Jennings et al., 1993; Valenzuela

\footnotetext{
Received Feb. 9, 1999; revised May 17, 1999; accepted May 21, 1999.

This work was supported intramurally by the National Institute for Mental Health and the National Institute for Neurological Diseases and Stroke and extramurally by a grant from National Institutes of Health to M.G. C.F. was supported by a post-doctoral fellowship and a grant from the Swiss National Science Foundation. We are very grateful to Mia Nichol for assistance and to Dr. Joshua R. Sanes for advice.

Correspondence should be addressed to Dr. Christian Fuhrer at his present address: Brain Research Institute, University of Zürich-Irchel, Winterthurerstrasse 190, CH-8057 Zürich, Switzerland.

Dr. Gautam's present address: Department of Pharmacological and Physiological Science, St. Louis University Medical School, St. Louis, MO 63104.

Dr. Sugiyama's present address: Hexos Inc., Bothell, WA 98021.

Dr. Hall's present address: Department of Physiology, University of California San Francisco School of Medicine, San Francisco, CA 94143.

Copyright (C) 1999 Society for Neuroscience 0270-6474/99/196405-12\$05.00/0
}

et al., 1995) appears to be a key component of the agrin receptor (Glass et al., 1996). MuSK is activated by agrin, and mice lacking MuSK are similar to agrin-deficient animals in that they lack AChR clusters (DeChiara et al., 1996). Agrin also induces tyrosine phosphorylation of the $\beta$ subunit of the AChR (Wallace et al., 1991; Meier et al., 1995; Ferns et al., 1996), a modification whose significance for AChR clustering is unclear at present (Meyer and Wallace, 1998). This phosphorylation appears not to occur through the direct action of MuSK (Fuhrer et al., 1997) but rather through one or several downstream kinases, possibly of the src family (Swope and Huganir, 1993, 1994; Fuhrer and Hall, 1996).

One protein closely associated with AChRs is rapsyn, a $43 \mathrm{kDa}$ peripheral membrane protein (Burden et al., 1983; LaRochelle and Froehner, 1986). Rapsyn is essential for AChR clustering: rapsyn-negative mice lack AChR clusters and their cultured myotubes fail to respond to agrin (Gautam et al., 1995), and rapsyn causes AChR aggregation upon coexpression in heterologous cells (Froehner et al., 1990; W. P. Phillips et al., 1991). When coexpressed in QT-6 fibroblasts, rapsyn is also able to aggregate MuSK and dystroglycan and to activate MuSK (Apel et al., 1995, 1997; Gillespie et al., 1996). On the basis of such indirect evidence, rapsyn has been proposed to link the AChR to the dystrophin/utrophin glycoprotein complex (Apel and Merlie, 1995); rapsyn has also been postulated to link the AChR to MuSK and to mediate interaction of the AChR with src-family kinases (Apel et al., 1997).

Although considerable evidence, based largely on expression in QT-6 fibroblasts, supports either the direct or indirect association 
of the AChR with other synaptic proteins, direct biochemical evidence for these interactions is lacking. To investigate these associations and the effect of agrin on them, we have isolated the AChR from extracts of $\mathrm{C} 2$ and rapsyn-negative myotubes and have used immunological methods to detect proteins that are specifically associated with it. Our data suggest that aneural myotubes contain preassembled AChR complexes, that agrin increases selected protein interactions, and that rapsyn mediates some but not all associations of other proteins with the AChR.

\section{MATERIALS AND METHODS}

Cell culture. Cell culture reagents were purchased from Life Technologies (Gaithersburg, MD). COS and $\mathrm{C} 2 \mathrm{C} 12$ muscle cells were grown at $37^{\circ} \mathrm{C}$ in $8 \% \mathrm{CO}_{2}$. COS cells were maintained in DMEM with $4.5 \mathrm{gm} / 1$ D-glucose containing $10 \%$ fetal bovine serum, $2 \mathrm{~mm}$ glutamine, and penicillin/streptomycin. $\mathrm{C} 2 \mathrm{C} 12$ mouse muscle cells were grown as myoblasts on 10 or $15 \mathrm{~cm}$ tissue culture dishes (Nunc, Naperville, IL) in DMEM supplemented with $20 \%$ fetal bovine serum, $0.5 \%$ chick embryo extract, $2 \mathrm{~mm}$ glutamine, and penicillin/streptomycin. Cells were shifted to fusion medium containing DMEM, 5\% horse serum, and $2 \mathrm{~mm}$ glutamine after reaching $90 \%$ confluence. Formation of myotubes was generally evident after $1 \mathrm{~d}$ in fusion medium. Cultures were harvested for experiments on day 2 in fusion medium, by which time contracting myotubes were detectable. Rapsyn -/- (clones 11-4 and 11-7) and rapsyn wild-type (clone 12-10) myoblasts were grown in the same basic medium as $\mathrm{C} 2$ cells, with an additional $4 \mathrm{U} / \mathrm{ml} \gamma$-interferon $(\gamma$-IFN). These cells were grown on dishes coated with $0.2 \%$ gelatin (Sigma, St. Louis, MO) and maintained at $33^{\circ} \mathrm{C}$ with $5 \% \mathrm{CO}_{2}$. To induce fusion, confluent cultures were shifted to $\mathrm{C} 2$ fusion medium and $37^{\circ} \mathrm{C}, 5 \% \mathrm{CO}_{2}$; the medium was replaced every $2 \mathrm{~d}$. Myotubes started to form after $\sim 1.5$ $\mathrm{d}$ and were used for experiments after 3 or $4 \mathrm{~d}$ in fusion medium.

Expression of agrin constructs. The C-terminal half of agrin isoforms was expressed in transfected COS cells to obtain soluble forms of agrin. Constructs encoding the most active, neural-specific isoform $\left(\mathrm{C}-\mathrm{Ag}_{12,4,8}\right)$ or the predominant muscle isoform (C-Ag $\mathrm{Ag}_{12,0,0}$ ) (Ferns et al., 1993) were expressed in COS cells using an adenovirus-mediated DEAE-dextran method of transfection (Forsayeth and Garcia, 1994). Because these two splice isoforms of agrin are most prominent and widely used, we refer to neural agrin as " 4,8 " and muscle agrin as " 0,0 " (e.g., see Figs. 2, 6). After transfection of agrin constructs, the medium was collected and replaced each day for $3 \mathrm{~d}$. The concentration of agrin in the medium was determined by immunoblotting using an agrin-specific antiserum and purified agrin of known concentration as a standard, as described previously (Fuhrer et al., 1997).

Generation of rapsyn - / - cell lines. To isolate mutant muscle cell lines, we made use of a transgenic mouse bearing a $\gamma$-IFN-inducible, temperature-sensitive T-antigen transgene (Jat et al., 1991) (Immortomouse, Charles River Laboratories, Wilmington, MA). Cells from different tissues of this mouse, including muscle, can be maintained for several passages in an undifferentiated state under permissive conditions $\left(33^{\circ} \mathrm{C}\right.$, with $\gamma$-IFN) in vitro (Morgan et al., 1994). Mice heterozygous for both rapsyn and the immortalizing transgene (double heterozygotes) were generated in crosses between mice bearing the transgene and rapsyn $+/-$ mice. Double heterozygotes were then crossed with rapsyn $+/-$ mice to generate rapsyn mutants and controls bearing the transgene. Litters from such crosses were dissected at embryonic day 18 (E18), and muscles from the forelimbs and hindlimbs of each pup were trypsinized. The resulting suspension of cells was diluted and plated on $3 \mathrm{~cm}$ plates and maintained at $33^{\circ} \mathrm{C}$ in $\mathrm{F} 10$ medium containing $20 \%$ fetal bovine serum, $3 \%$ chick embryo extract, and $4 \mathrm{U} / \mathrm{ml} \gamma$-IFN. Pups from each litter were genotyped by PCR of tail DNA within $2 \mathrm{~d}$ of initial plating; cell cultures from mutants and controls that tested positive for the transgene were then trypsinized, counted, and replated at clonal density. Colonies were allowed to develop over the next $10 \mathrm{~d}$, and each colony was expanded. We picked three clonal cell lines for further studies: 11-4 and 11-7 are rapsyn $-/-$ lines and $12-10$ is a wild-type (rapsyn $+/+$ ) cell line. Analysis of 11-4 versus 11-7 cells revealed no clonal variability in the association of AChRs with postsynaptic proteins (data not shown). We used 11-7 for most experiments, however, because they routinely formed myotubes more efficiently than 11-4.

Antibodies. Affinity-purified rabbit polyclonal antibodies against rapsyn, designated 5943 (W. D. Phillips et al., 1991), were a generous gift from the late Dr. J. P. Merlie and from Dr. J. R. Sanes (Washington
University, St. Louis, MO). In immunoblot experiments with cultured muscle cells, the antibody recognized a major protein of $\sim 43 \mathrm{kDa}$ that was specifically absent from rapsyn $-/-$ myotubes and thus represents rapsyn (see Fig. 3). A rabbit polyclonal antiserum, $\alpha \mathrm{DRP}$, reactive with utrophin (Ohlendieck et al., 1991), was a gift from Dr. K. P. Campbell (University of Iowa, Iowa City, IA). In immunoblots made with extracts from cultured myotubes, this antibody labeled a single protein band of $\sim 400 \mathrm{kDa}$, whose mobility was very similar to utrophin found in purified sarcolemma of mouse skeletal muscle (Ohlendieck et al., 1991). The rabbit antiserum recognizing $\beta$-dystroglycan was made against a peptide corresponding to the $\mathrm{C}$-terminal 20 amino acid of mouse $\beta$-dystroglycan and was produced commercially by Research Genetics (Huntsville, AL). Immunoblotting with preimmune serum and immunoprecipitations with an excess of free $\beta$-dystroglycan immunizing peptide established the specificity of the antibody (J. E. Sugiyama and Z. W. Hall, unpublished observations). In all cases, $\beta$-dystroglycan was detected as a band of $\sim 46$ $\mathrm{kDa}$, similar to its molecular weight in dystrophin/utrophin glycoprotein complexes purified from rabbit skeletal muscle (IbraghimovBeskrovnaya et al., 1992). In addition, a mouse monoclonal antibody against $\beta$-dystroglycan, purchased from Novocastra Labs (Burlingame, $\mathrm{CA}$ ), reacted with a protein of the same molecular weight in immunoblots made from $\mathrm{C} 2$ myotubes (data not shown), showing that our antibody indeed recognizes $\beta$-dystroglycan in cultured muscle cells. $\mathrm{mAb124}$, a rat monoclonal antibody against the $\mathrm{AChR} \beta$ subunit, was a kind gift from Dr. J. Lindstrom (University of Pennsylvania, Philadelphia, PA). The mouse monoclonal antiserum mAb 88B, reactive with the AChR $\gamma$ and $\delta$ subunits, and mAb SYN1351 (Froehner et al., 1987), a mouse monoclonal antibody reactive with all syntrophin isoforms $(\alpha 1$, $\beta 1$, and $\beta 2$ ) (Peters et al., 1994), were generously provided by Dr. S. C. Froehner (University of North Carolina, Chapel Hill, NC). In C2 myotube extracts, syntrophin isoforms were detected as three major protein bands between 55 and $65 \mathrm{kDa}$ (see Fig. 2). A rat monoclonal antiserum recognizing the mouse transferrin receptor RI7 217 (Lesley et al., 1989) was a generous gift from Dr. J. Lesley (The Salk Institute, San Diego, CA). To detect src-related kinases, we used src-CT, a rabbit polyclonal antibody reactive with at least src, fyn, and yes (Santa Cruz Biotechnology, Santa Cruz, CA) (Fuhrer and Hall, 1996). The rabbit polyclonal antiserum recognizing MuSK was as described (Fuhrer et al., 1997). For phosphotyrosine immunoblotting, a mixture of two commercially available mouse monoclonal antibodies was used, 4G10 (Upstate Biotechnology, Lake Placid, NY) and PY20 (Transduction Labs, Lexington, KY).

Isolation of AChRs and co-precipitation. To examine association of postsynaptic proteins with the AChR, myotubes were rinsed on ice with PBS supplemented with $1 \mathrm{~mm}$ Na-orthovanadate and $50 \mathrm{~mm} \mathrm{NaF}$ and extracted at $4^{\circ} \mathrm{C}$ in lysis buffer. For these assays, most of the chemicals were purchased from Sigma. The conditions for lysis were mild, i.e., $1 \%$ digitonin, $50 \mathrm{~mm} \mathrm{NaCl}, 30 \mathrm{~mm}$ triethanolamine, $\mathrm{pH} 7.5$, $5 \mathrm{~mm}$ EGTA, $5 \mathrm{~mm}$ EDTA, $50 \mathrm{~mm} \mathrm{NaF}, 2 \mathrm{~mm}$ Na-orthovanadate, $10 \mathrm{~mm} p$-nitrophenylphosphate, $50 \mu \mathrm{M}$ phenylarsine-oxide, $1 \mathrm{~mm}$ benzamidine, $1 \mathrm{~mm} N$-ethylmaleimide, $1 \mathrm{~mm}$ Na-tetrathionate, $1 \mathrm{~mm}$ PMSF, $25 \mu \mathrm{g} / \mathrm{ml}$ aprotinin, and $25 \mu \mathrm{g} / \mathrm{ml}$ leupeptin. Cells were lysed for $30 \mathrm{~min}$, and insoluble material, such as nuclei and cytoskeletal elements, was removed by centrifugation at $18,000 \times g$ for $5 \mathrm{~min}$. To precipitate the $\mathrm{AChR}$, the cleared lysates were incubated with $\alpha$-bungarotoxin $(\alpha$-BT) coupled to Sepharose beads ( $\mathrm{Gu}$ and Hall, 1988). In the case of control samples, we added an excess $(10 \mu \mathrm{M})$ of free uncoupled $\alpha$-bungarotoxin to lysates to compete with $\mathrm{AChR}$ binding to the resin. Other control samples were precipitated with uncoupled Sepharose beads. Beads were then washed twice with wash buffer 1 ( $0.4 \%$ digitonin, $470 \mathrm{mM} \mathrm{NaCl}, 30$ mm triethanolamine, $\mathrm{pH} 7.5$, $5 \mathrm{~mm}$ EGTA, $5 \mathrm{~mm}$ EDTA, $2 \mathrm{~mm} \mathrm{Na}-$ orthovanadate, $1 \mathrm{mM}$ PMSF, $10 \mathrm{~mm}$-nitrophenylphosphate, $50 \mu \mathrm{M}$ phenylarsine-oxide, $50 \mathrm{~mm} \mathrm{NaF}$ ) and twice in wash buffer 2 (same as 1 but containing $120 \mathrm{~mm} \mathrm{NaCl}$ ) and boiled in SDS-PAGE sample buffer. The proteins were separated by reducing SDS-PAGE and transferred to nitrocellulose membranes. To detect AChR-associated proteins, the nitrocellulose was probed with the appropriate antibodies, and immunoreactive bands were visualized using horseradish peroxidase-conjugated secondary antibodies and enhanced chemiluminescence (ECL, Amersham Corporation, Arlington Heights, IL). Some immunoblots were stripped by incubating them for $20 \mathrm{~min}$ in $200 \mathrm{~mm}$ glycine, $0.1 \%$ Tween $20, \mathrm{pH} 2.5$; the blots were then reprobed with src-CT to examine src-related kinases or with mAb 124 or mAb $88 \mathrm{~B}$ to confirm that equal amounts of AChRs were present in all lanes. Experiments were repeated at least four times, and representative samples are shown in Figures 2 and 6. Quantitation of ECL immunoblotting data was performed by 
scanning films containing gray, nonsaturated signals with a computerized densitometer (LaCie Silverscanner IV) and using the NIH Image 1.54 software. Scanning data were evaluated by one-way ANOVA followed by pair-wise Bonferroni's $t$ tests.

To study tyrosine phosphorylation of AChRs, AChR-associated MuSK, and total MuSK, myotubes were treated with agrin and extracted in lysis buffer as described above. Cleared lysates were split into two parts and either incubated with $\alpha$-bungarotoxin-Sepharose beads to isolate the AChR and receptor-associated MuSK or with MuSK antibodies followed by protein A-Sepharose to precipitate MuSK. Beadprecipitated proteins were eluted into SDS sample buffer, subjected to SDS-PAGE, and analyzed by phosphotyrosine immunoblotting. Because of the similarities in the precipitation protocols using MuSK antibodies and toxin-Sepharose, we refer to the latter as "Tox-IP" in Figures 7 and 5 , although no antibodies are used in this case. The experiments were performed three times, and representative samples are shown in Figure 7. Evaluation was performed by densitometric scanning of nonsaturated signals and statistical analysis as described above.

These experiments revealed the presence of a protein complex in C2 myotubes containing $\mathrm{AChRs}$ in association with rapsyn, MuSK, srcrelated kinases, $\beta$-dystroglycan, and utrophin. To test the relative strength of these protein interactions, we used a range of progressively more stringent conditions. These were based on the lysis and wash buffers detailed above, with the following substitutions: (1) digitonin was replaced by Nonidet P-40 (NP-40) or Triton X-100 (Tx-100) in lysis and wash buffers; (2) digitonin was replaced with a fixed concentration of $1 \%$ Tx-100 in both lysis and wash buffers; (3) digitonin was replaced with fixed concentrations of $1 \% \mathrm{Tx}-100$ and $0.5 \%$ deoxycholate in both lysis and wash buffers; (4) same as (3) but $470 \mathrm{~mm} \mathrm{NaCl}$ was included in the lysis buffer, i.e., cell lysis was performed in the presence of high salt; and (5) in addition, an extremely mild procedure was applied, in which the lysis buffer contained digitonin as described, but all wash buffers contained only low salt, i.e., $120 \mathrm{~mm} \mathrm{NaCl}$. Over this range of conditions, few changes in protein binding were observed. Substituting digitonin with any other detergent abolished association of AChRs with $\beta$-dystroglycan, whereas under condition (4), no agrin-dependent increase of the AChRMuSK interaction was seen.

Fluorescence microscopy. To visualize the distribution of AChR on the surface of rapsyn $-/-$ and wild-type myotubes, these cells were grown and fused on gelatin-coated chamber slides (Nunc). Myotubes were treated with or without $0.1 \mathrm{~nm}$ neural agrin for $16 \mathrm{hr}$ and incubated with $0.5 \mu \mathrm{g} / \mathrm{ml}$ rhodamine-conjugated $\alpha$-bungarotoxin. After washing and fixation in $2 \%$ paraformaldehyde, cells were mounted with $p$-phenylenediamine and examined under a Nikon MicrophotFXA fluorescence microscope at a final magnification of $400 \times$.

\section{RESULTS}

\section{AChRs are associated with rapsyn in $\mathbf{C 2}$ myotubes}

We examined the associations of AChRs with other proteins by extracting the AChR from $\mathrm{C} 2$ myotubes in a buffer containing $1 \%$ digitonin, a mild detergent, precipitating it with $\alpha$-bungarotoxin $(\alpha$-BT) conjugated to Sepharose beads, and probing immunoblots of the precipitated proteins using the relevant antibodies. To test whether proteins were bound to the resin specifically through their association with the $\mathrm{AChR}$, free $\alpha$-BT was added to extracts before the purification or unconjugated Sepharose was used, as described previously (Fuhrer et al., 1997).

In our initial experiments, we looked for the presence of the protein rapsyn, because it has been postulated to be associated with the AChR as the result of cross-linking experiments (Burden et al., 1983) and because of its ability to cluster AChRs in heterologous cells (Froehner et al., 1990; W. P. Phillips et al., 1991; Gillespie et al., 1996; Apel et al., 1997). Other observations that implied a complex between rapsyn and the AChR include their 1:1 stoichiometry in C2 myotubes (LaRochelle and Froehner, 1987) and structural investigations that revealed a protein, presumably rapsyn, associated with Torpedo AChR on its cytoplasmic surface (Unwin, 1993). Our immunoblotting experiments with rapsyn-specific antibodies revealed that the precipitated AChR is indeed associated with an immunopositive band that

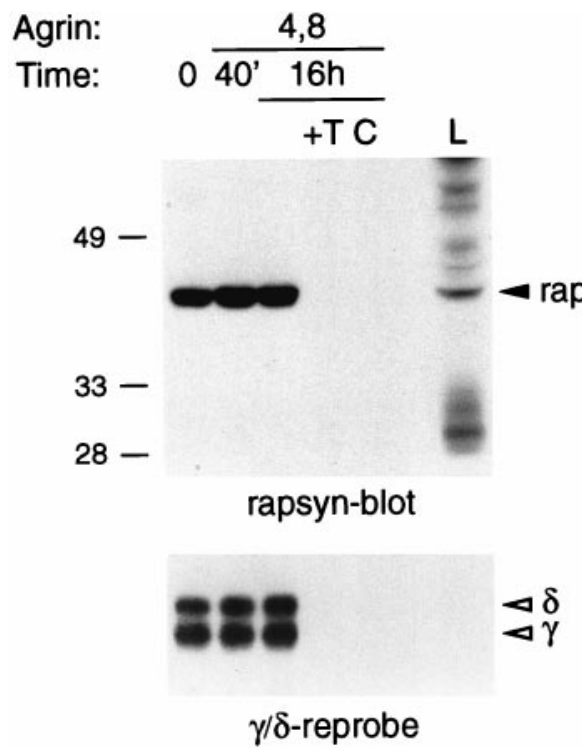

Figure 1. Rapsyn is associated with the AChR. C2 myotubes were treated with $5 \mathrm{~nm}$ neural agrin as indicated and lysed in a buffer containing $1 \%$ digitonin. AChRs were isolated using $\alpha$-BT coupled to Sepharose beads; as controls, an excess $(10 \mu \mathrm{M})$ of free soluble toxin was added $(+T)$ or unconjugated Sepharose was used $(C)$. Samples were analyzed by SDS-PAGE and immunoblotting with a rapsyn-specific antiserum. For the bottom part, the blot was stripped and reprobed with mAb $88 \mathrm{~b}$, which recognizes the AChR $\gamma$ and $\delta$ subunits. $L$ indicates a fraction $(0.3 \%)$ of the total lysate.

migrates as a protein of $43 \mathrm{kDa}$ and represents rapsyn (Fig. 1). The band was not present when an excess of free toxin was added to the extract or when unconjugated Sepharose was used, confirming the specificity of the interaction. By comparing the amount of protein precipitated with the amount of rapsyn in the original extract, we estimate that $1.13 \pm 0.29 \%$ of the total rapsyn is specifically bound to the toxin beads (mean $\pm \mathrm{SD}$; data from six experiments). Because only $14.9 \%$ of the total AChR in C2 lysates is recovered on $\alpha$-BT-Sepharose (Fuhrer et al., 1997), we calculate that at least $7.5 \%$ of the total rapsyn in the extract is associated with the AChR (Table 1). Because rapsyn is likely to be poorly extracted relative to the AChR (Froehner, 1991), our results are consistent with the association of a significant proportion of the total rapsyn in muscle cells with the AChR.

To our knowledge, this is the first demonstration of a specific co-precipitation of soluble rapsyn with the AChR in extracts of muscle cells. Biochemical co-purification of these two proteins has proven to be difficult (Froehner, 1991; Bezakova and Bloch, 1998; Colledge and Froehner, 1998b), and a recent report showed protein co-precipitation but did not test the specificity of the proposed interaction or mention proteins that are excluded from the precipitation procedure (Mitsui et al., 1996). Another recent study described weak binding between recombinant $\mathrm{AChR}$ and rapsyn proteins using protein overlay assays (Buckel et al., 1998). The difficulties in biochemical co-purification of rapsyn and the AChR from extracts of muscle or Torpedo most likely originate from difficulties in extracting rapsyn from the cytoskeleton and its protease sensitivity. With respect to the latter, we have observed that within hours after cell extraction, the amounts of rapsyn and the AChR in the cell lysate decrease substantially (C. Fuhrer and Z. W. Hall, unpublished observations). For these reasons, we assume that our observed interaction originates from a 
Table 1. Protein interactions with the AChR

\begin{tabular}{|c|c|c|c|c|c|c|c|}
\hline \multirow[b]{3}{*}{ Protein } & \multicolumn{5}{|c|}{ Wild-type cells $^{a}$} & \multirow{2}{*}{\multicolumn{2}{|c|}{$\frac{\text { Rapsyn }-/- \text { cells }}{\text { Mild extraction }}$}} \\
\hline & \multicolumn{3}{|c|}{ Mild extraction } & \multicolumn{2}{|c|}{ Stringent extraction } & & \\
\hline & -Agrin & + Agrin & Efficiency $^{b}(\%)$ & -Agrin & + Agrin & -Agrin & + Agrin \\
\hline MuSK & + & ++ & $1.94 \pm 0.13$ & + & + & + & + \\
\hline Rapsyn & + & + & $7.58 \pm 1.94$ & + & + & N/A & N/A \\
\hline src-related kinases & + & + & $0.35 \pm 0.07$ & + & + & + & + \\
\hline Utrophin $^{c}$ & + & + & $0.48 \pm 0.17$ & + & + & - & - \\
\hline$\beta$-dystroglycan ${ }^{c}$ & + & + & $0.30 \pm 0.04$ & - & - & - & - \\
\hline Syntrophin & - & - & 0 & ND & ND & ND & ND \\
\hline Transferrin receptor & - & - & 0 & $\mathrm{ND}$ & ND & ND & ND \\
\hline
\end{tabular}

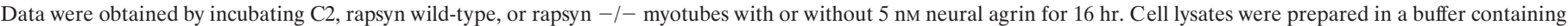

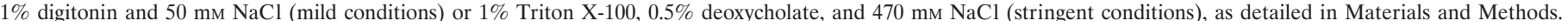
AChRs were isolated using $\alpha$-bungarotoxin-Sepharose, and associated proteins were identified by immunoblotting. ND, Not done; N/A, not applicable.

${ }^{a}$ As wild-type cells, C2 and rapsyn wild-type myotubes (12-10) were used.

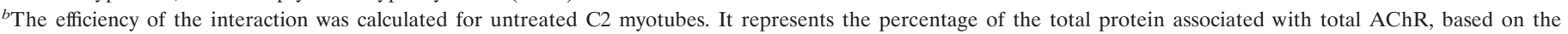
observation that $14.9 \%$ of AChRs in a cell extract can be isolated on $\alpha$-BT-Sepharose (Fuhrer et al., 1997). Data represent mean \pm SD of at least five experiments.

${ }^{c}$ For utrophin and $\beta$-dystroglycan, substantial non-specific binding occurs to the Sepharose resin.

much more pronounced in vivo association between rapsyn and the AChR.

\section{Association of the AChR with other synaptic proteins}

We used the same method to investigate the association of the AChR with other postsynaptic proteins. Using specific antibodies, we looked for the presence of three proteins that are part of the dystrophin/utrophin glycoprotein complex, $\beta$-dystroglycan, utrophin, and syntrophin. Small amounts of the first two proteins were specifically associated with the AChR (Fig. 2A,B). A $400 \mathrm{kDa}$ band was immunopositive for utrophin, and a protein of $46 \mathrm{kDa}$ was reactive with $\beta$-dystroglycan antibodies. In both cases, some of the observed binding was nonspecific, because it could not be competed with excess toxin and it also occurred to unconjugated Sepharose. There was a consistent and statistically significant difference between toxin beads and these controls, however, indicating that utrophin, as well as $\beta$-dystroglycan, is specifically associated with the AChR (also see Fig. 6). In both cases, the amount of bound protein was low; we calculate that $\sim 0.30 \%$ of total $\beta$-dystroglycan and $0.48 \%$ of total utrophin are bound to the AChR in the cell extracts (Table 1). No evidence was found for binding of syntrophin, the third member of the complex tested. Using a monoclonal antibody, mAb SYN1351, that recognized all three major syntrophin isoforms, $\alpha 1, \beta 1$, and $\beta 2$ (Peters et al., 1994 ), in $C 2$ myotube extracts, no immunopositive protein was detected bound to toxin beads (Fig. 2D). The failure to detect association with syntrophin indicates that the binding of $\beta$-dystroglycan and utrophin is specific and does not reflect nonselective protein aggregation. As a further control, we also tested for the presence of an unrelated membrane protein, the transferrin receptor, which was not associated with AChRs under any of the conditions tested (Table 1) (Fuhrer et al., 1997).

The effect of agrin on the interaction of the AChR with rapsyn, MuSK, src-family kinases, and other proteins

We then tested the effect of agrin treatment on the interaction of the AChR with rapsyn and other proteins. Agrin did not change the amount of rapsyn bound to the AChR. Although occasional variations were seen, no consistent effect of agrin on the association was observed (Fig. 1). Even after a $16 \mathrm{hr}$ treatment with a high dose ( $5 \mathrm{~nm}$ ) of neural agrin, conditions under which AChR cluster formation is maximal (Ferns et al., 1996), the association remained unchanged as compared with untreated cells, suggesting that the interaction of rapsyn with AChRs in muscle cells is independent of the agrin signaling pathway.

We have reported previously that the AChR in $\mathrm{C} 2$ myotubes is associated with both of the src-family kinases, src and fyn (Fuhrer and Hall, 1996), and with the receptor tyrosine kinase MuSK, and that agrin treatment increases the association of MuSK with AChRs (Fuhrer et al., 1997). When we examined the effect of agrin on the association of the AChR with src-family kinases, however, we found results that were similar to those seen for rapsyn. Using an antiserum, src-CT, that reacts with several src-family members including src, fyn, and yes, we found no effect of agrin treatment on the amount of these proteins associated with the AChR (Fig. 2C). We also found no consistent effect of agrin on the association of utrophin and $\beta$-dystroglycan with the $\mathrm{AChR}$, although variations in the binding were occasionally observed (Fig. 2A, $B$; also see Fig. $6 C$ ).

\section{Characteristics of the AChR-protein interactions}

To investigate the strength of the observed protein interactions with the $\mathrm{AChR}$, we used a range of progressively more stringent conditions to extract $\mathrm{C} 2$ myotubes, including up to $1 \%$ Triton $\mathrm{X}-100,0.5 \%$ deoxycholate, and $470 \mathrm{~mm} \mathrm{NaCl}$ (see Materials and Methods). Although most associations were unchanged, we did find two differences in these experiments. First, substituting digitonin with any other detergent inevitably abolished binding of the $\mathrm{AChR}$ to $\beta$-dystroglycan without affecting other constitutive interactions (Table 1). We were thus able to observe a complex of the AChR in association with utrophin, kinases, and rapsyn, but without $\beta$-dystroglycan. Second, under the harshest conditions tested, agrin failed to increase the association of the AChR with MuSK (Table 1). These data indicate that some protein interactions are very fragile and that we most likely disrupt protein complexes during even the mildest extraction procedures. Our calculations on the stoichiometries of the protein interactions are thus minimal estimates of the associations as they occur in intact cells and are likely to be merely an indication of much more pronounced interactions in vivo. Furthermore, MuSK appears to interact with the AChR in two ways. The first association is independent of agrin and resistant to harsh conditions, whereas the second is induced by agrin and disrupted by stringent extrac- 
A

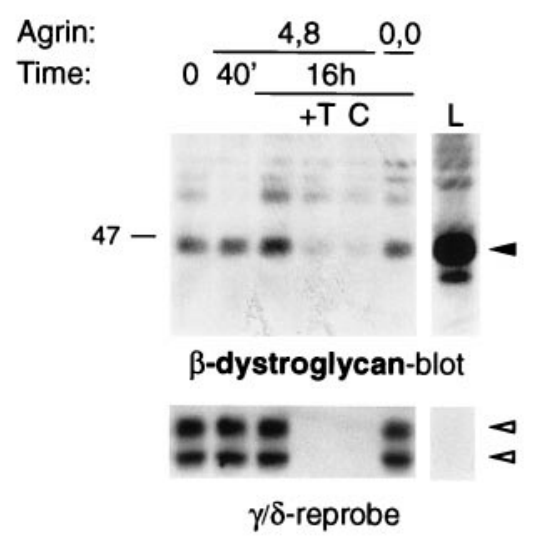

C

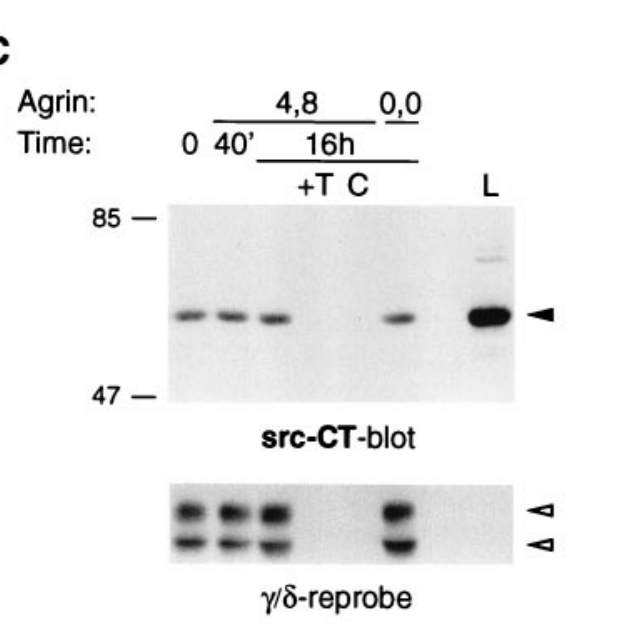

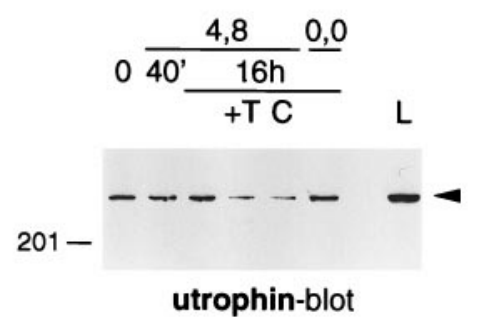

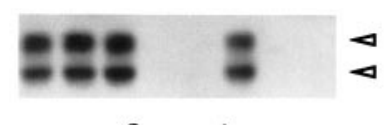

$\gamma / \delta$-reprobe
B

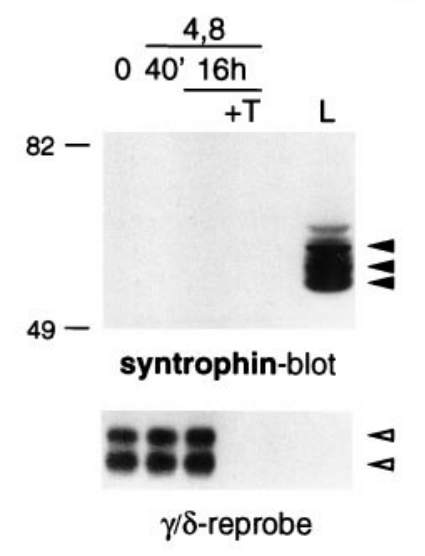

Figure 2. Protein associations with the $\mathrm{AChR}$ in $\mathrm{C} 2$ myotubes. Myotubes were incubated with $5 \mathrm{~nm}$ neural $(4,8)$ or muscle $(0,0)$ agrin as indicated. Cells were then extracted under mild conditions, using $1 \%$ digitonin, and AChRs were precipitated with $\alpha$-BT-Sepharose. As controls, an excess $(10 \mu \mathrm{M})$ of free toxin was added $(+T)$, or in some experiments unconjugated Sepharose was used $(C)$. Precipitates were analyzed by immunoblotting using specific antibodies as indicated. The AChR content in each lane was visualized by reprobing stripped blots with an antiserum, $\mathrm{mAb} 88 \mathrm{~b}$, reactive with the AChR $\gamma$ and $\delta$ subunits. For comparison, a fraction $(0.2 \%)$ of the total cell lysate was analyzed $(L)$. Solid arrowheads indicate the proteins detected by the antibodies used for immunoblotting; open arrowheads point to the AChR $\gamma$ and $\delta$ subunits. tion buffers. Thus, different mechanisms appear to underlie constitutive as opposed to agrin-induced association of MuSK with the AChR. Finally, the range of detergent conditions allowed us to partially dissect the AChR protein complex. Because $\beta$-dystroglycan is selectively lost under harsh conditions, the observed binding of other proteins to the $\mathrm{AChR}$ does not require its presence. Thus, in the assembled AChR complex in myotubes, $\beta$-dystroglycan does not appear to link other proteins, in particular, utrophin, to the AChR; instead, these proteins interact with the AChR independently of $\beta$-dystroglycan.

\section{Production and characterization of rapsyn -/- cell lines}

Because rapsyn has been proposed as a primary adaptor and anchoring protein of the $\mathrm{AChR}$, linking it to other proteins, we wished to investigate its role in the association of the AChR with the proteins mentioned before. For this purpose we made use of rapsyn-deficient muscle cell lines bearing an immortalizing SV40 T-antigen transgene (Jat et al., 1991; Morgan et al., 1994). Rapsyn mutant mice bearing the transgene were obtained in crosses between rapsyn heterozygotes positive for the SV40 T-antigen transgene and rapsyn $+/-$ mice (see Materials and Methods). Cells dissociated from limb muscles of E18 embryos were plated at clonal density under permissive conditions $\left(33^{\circ} \mathrm{C}, \gamma\right.$-interferon $)$ for the isolation of muscle cell lines. Each colony was expanded and tested for fusion $\left(37^{\circ} \mathrm{C}\right.$, no $\gamma$-interferon $)$. Two of the resulting rapsyn $-/-$ cell lines (11-4 and 11-7) formed myotubes that displayed spontaneous contractions and appeared healthy (see
Fig. 4). No significant difference in overall morphology was seen as compared with the control wild-type muscle cell line (12-10, rapsyn $+/+$ ) generated from a wild-type littermate. However, for both mutant and wild-type cell lines, the overall efficiency of fusion and myotube formation was lower than that seen with $\mathrm{C} 2$ myotubes.

The overall amounts of the AChR, and the proteins associated with it, were compared in extracts of the rapsyn -/- and rapsyn wild-type cell lines (11-7 and 12-10) by immunoblotting (Fig. 3). The cellular levels of all proteins examined, including the AChR, utrophin, $\beta$-dystroglycan, syntrophin, src-related kinases, and MuSK, were indistinguishable in the two cell lines. Only rapsyn, which was undetectable in the mutant cells, was different. These results show that rapsyn does not affect the overall levels of these proteins, nor is it required for the formation of healthy myotubes in vitro.

When myotubes from the two cell lines were examined for the presence of AChR clusters using rhodamine-conjugated $\alpha$-BT and fluorescence microscopy, the wild-type myotubes showed occasional clusters, but the mutant cells had none (Fig. 4). Moreover, when treated with agrin, the wild-type myotubes formed many AChR clusters, but the mutant cells failed to form any aggregates at all. After treatment of myotubes with $0.1 \mathrm{~nm}$ neural agrin for $16 \mathrm{hr}$, clusters were absent in the mutant cells, whereas an abundance of clusters was visible on the wild-type myotubes, similar to observations with $\mathrm{C} 2$ myotubes (Fig. 4; data not shown). The complete absence of AChR aggregates, in both 


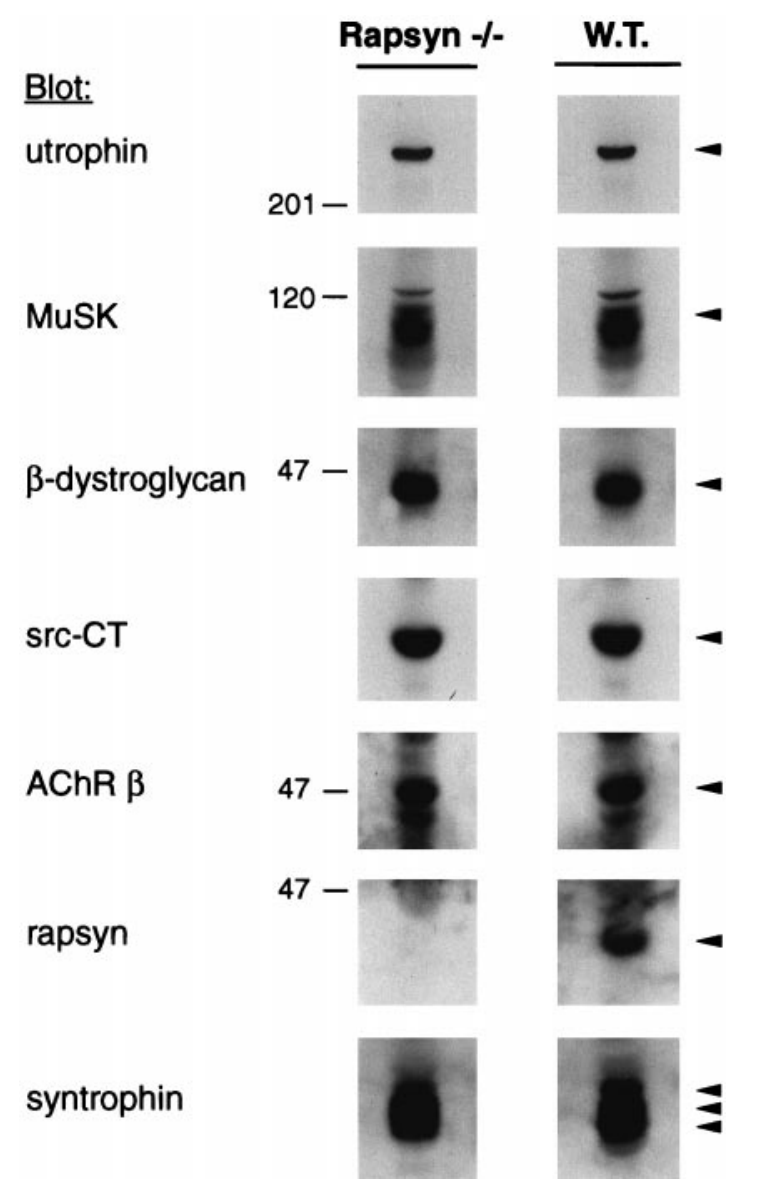

Figure 3. Analysis of postsynaptic proteins in rapsyn -/- and wild-type myotubes. Cells (11-7 and 12-10) were lysed in a buffer containing $1 \%$ NP-40, and protein-matches fractions, $\sim 1 \%$ of the extracts, were subjected to immunoblotting using utrophin-, MuSK-, or $\beta$-dystroglycanspecific antibodies. Blots were stripped and reprobed with the src-CT antibody; in a second round of stripping and reprobing, mAb 124 antibodies recognizing the AChR $\beta$ subunit were used. Parallel lysates were analyzed by immunoblotting with rapsyn- or syntrophin-specific antisera. Arrowheads indicate the proteins recognized by the respective antibodies.

untreated and agrin-treated mutant cells, was striking and is in agreement with results from cultured primary myotubes derived from rapsyn -/- mice (Gautam et al., 1995).

\section{AChR-protein interactions in rapsyn -/- myotubes}

We then used the rapsyn $-/-$ myotubes in our standard precipitation experiments to determine whether rapsyn is required for each of the other protein associations with the AChR that we detected. We first looked to determine whether rapsyn is required for MuSK association with the AChR, because experiments in transfected QT-6 fibroblasts had suggested that rapsyn associates independently with both the AChR and MuSK (Gillespie et al., 1996; Apel et al., 1997). When rapsyn -/- myotubes were examined, however, MuSK was found to be associated with the AChR in a specific manner and with a stoichiometry comparable to that found in C2 myotubes (Fig. 5) (Fuhrer et al., 1997). We calculate that $1.46 \pm 0.46 \%$ of the total MuSK in extracts is associated with the $\mathrm{AChR}$ (mean $\pm \mathrm{SD}$ from six experiments; see also Table 1) under conditions in which the efficiency of $\mathrm{AChR}$ precipitation is the same in the two cell lines. We conclude that the constitutive association of MuSK with the AChR does not require rapsyn.

We found similar results when we examined the association of

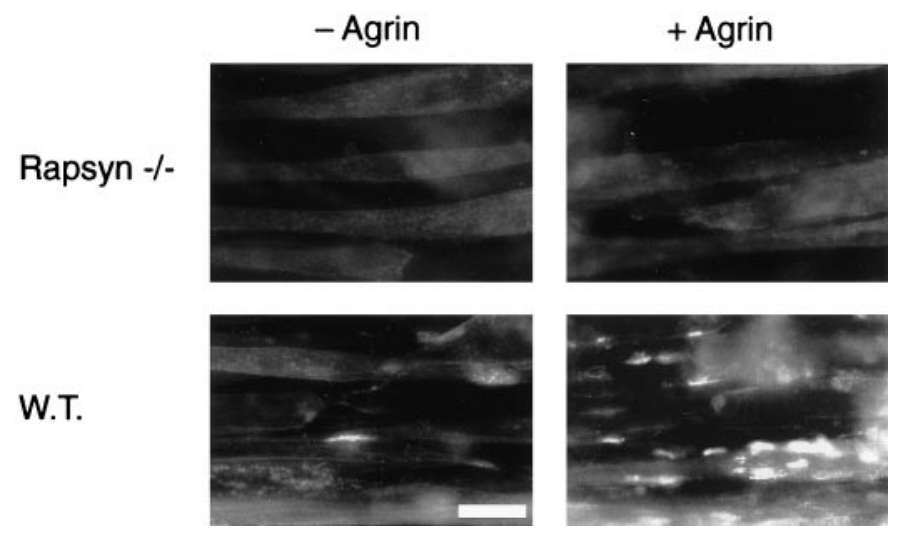

Figure 4. Distribution of AChRs on the surface of agrin-treated rapsyn $-/-$ and wild-type myotubes. 11-7 and 12-10 cells were grown and fused on chamber slides and incubated with or without $0.1 \mathrm{~nm}$ neural agrin for $16 \mathrm{hr}$. Surface AChRs were visualized by incubating cells with $0.5 \mu \mathrm{g} / \mathrm{ml}$ rhodamine-conjugated $\alpha$-BT, fixing in $2 \%$ paraformaldehyde, and examination by fluorescence microscopy. In rapsyn $-/-$ myotubes, both spontaneous and agrin-induced AChR clusters are completely absent, whereas wild-type cells show increased cluster formation in response to agrin. Scale bar, $20 \mu \mathrm{m}$.
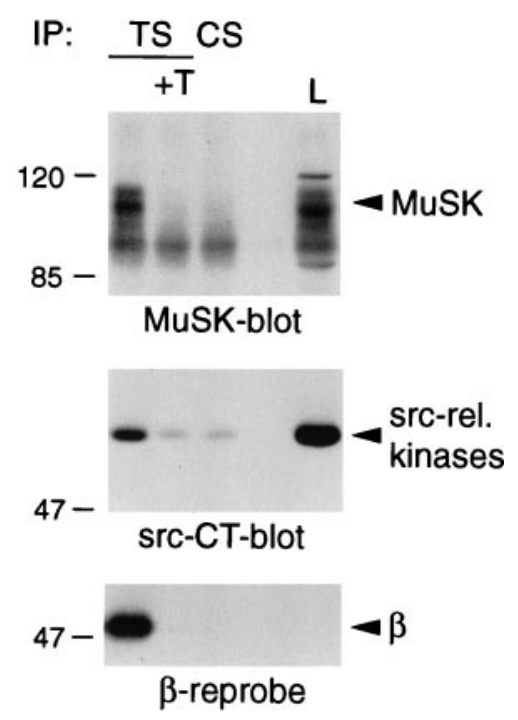

Figure 5. Association of the AChR with MuSK and src-related kinases in rapsyn $-/-$ myotubes. Myotubes lacking rapsyn were lysed in a buffer containing $1 \%$ digitonin, and AChRs were precipitated with $\alpha$-BT coupled to Sepharose beads $(T S)$. As controls, an excess $(10 \mu \mathrm{M})$ of free toxin was added $(+T)$, or unconjugated Sepharose was used $(C S)$. AChRassociated proteins were detected by immunoblotting using MuSK or src-CT antibodies, and the presence of the AChR was confirmed by stripping the src-CT blot and reprobing it with $\mathrm{mAb} 124$ reactive with the AChR $\beta$ subunit. $L$ represents $0.2 \%$ of the total lysate.

the src-related kinases with the AChR in rapsyn -/- myotubes (Fig. 5). The proportion of src-family kinases in the total extract that was associated with the $\operatorname{AChR}(0.30 \pm 0.13 \%$ in six experiments) was not significantly different from that found in $\mathrm{C} 2$ myotubes (Fuhrer and Hall, 1996). Thus, in muscle cells, rapsyn is also dispensable for binding of src-related kinases to the $\mathrm{AChR}$, although in transfected fibroblasts rapsyn is associated with cell-endogenous kinase activity (Qu et al., 1996).

Different results were found when the isolated AChR from rapsyn $-/-$ myotubes was examined for the presence of proteins associated with the dystrophin/utrophin glycoprotein complex 
A

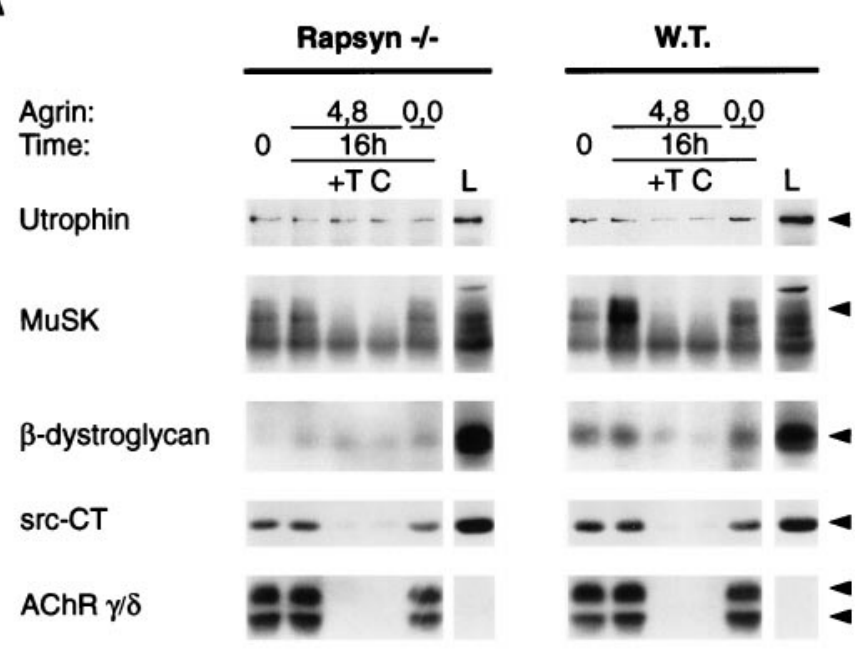

B

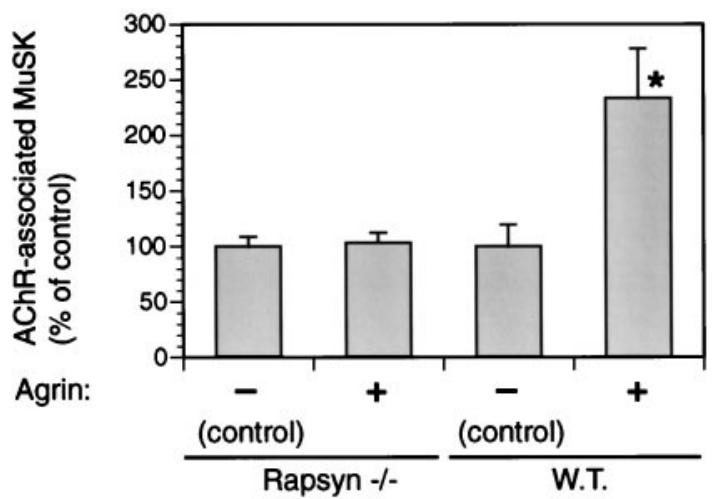

C
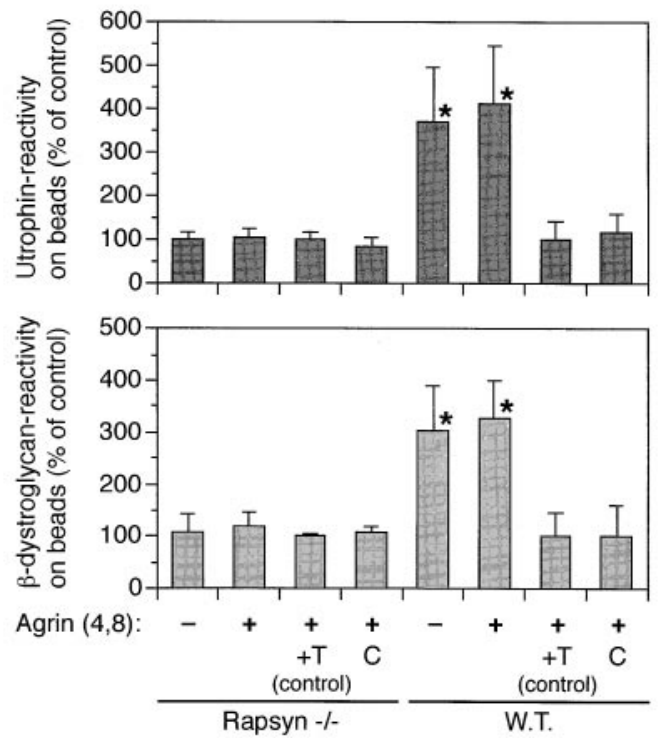

Figure 6. Effect of agrin on association of proteins with the AChR in rapsyn $-/-$ myotubes. $A$, Myotubes lacking rapsyn (11-7) and control wild-type cells $(12-10)$ were treated for $16 \mathrm{hr}$ with $5 \mathrm{~nm}$ of neural $(4,8)$ or muscle $(0,0)$ agrin as indicated. Cells were extracted under mild conditions, using $1 \%$ digitonin, and $\mathrm{AChR}$-associated proteins were detected by $\alpha$-BT-Sepharose precipitation and immunoblotting using the indicated antibodies. As a standard, $0.2 \%$ of the total lysate was analyzed $(L)$. Arrowheads point to the proteins recognized by the respective antibodies.
(Fig. 6). In contrast to results obtained with $\mathrm{C} 2$ or rapsyn wildtype myotubes, no evidence was found for specific binding of utrophin or $\beta$-dystroglycan to the AChR in the mutant cells (Fig. $6 A, C)$. Even under the mildest conditions of extraction, $1 \%$ digitonin and a total salt concentration of $150 \mathrm{~mm}$ in lysis and wash buffers, we could not detect specific associations. Analysis of several experiments showed that the association of the AChR with utrophin and $\beta$-dystroglycan is statistically significant in the wild-type cells, although some background binding of these proteins occurs to the Sepharose resin (Fig. 6C). In rapsyn-deficient myotubes, in contrast, no significant difference was found between $\alpha$-BT-Sepharose and control samples including excess free toxin and uncoupled Sepharose, ruling out a specific association of the AChR with utrophin and $\beta$-dystroglycan in these cells. Thus, rapsyn is required for the association of the AChR with two proteins of the dystrophin/utrophin glycoprotein complex, utrophin and $\beta$-dystroglycan.

Finally, we examined the effects of agrin treatment on the associations of the various proteins with the AChR in rapsyn -/myotubes. No effect was seen in any case. In particular, agrin did not increase the association of MuSK with the AChR. In contrast, in $\mathrm{C} 2$ and rapsyn wild-type myotubes, agrin increased the association by $\sim 2.5$-fold, as shown in Figure $6 B$ and as reported previously (Fuhrer et al., 1997). These results suggest that MuSK associates with the AChR in two ways, in a rapsyn-independent and a rapsyn-dependent mode, and that the latter occurs as a response to agrin. These two modes of interaction are consistent with the observations from $\mathrm{C} 2$ myotubes using mild and stringent extraction buffers, as described above.

These data indicate that in muscle cells, rapsyn mediates interactions of the AChR with two components of the dystrophin/ utrophin glycoprotein complex, utrophin and $\beta$-dystroglycan, but not with src-related kinases. In the case of MuSK, it is not involved in the constitutive interaction but is necessary for the increased association observed after treatment with agrin. Because rapsyn $-/-$ myotubes do not form any AChR clusters, either spontaneously or in response to agrin, the rapsynindependent binding of src-related kinases and MuSK in these cells must occur to diffusely distributed AChRs.

In summary, in myotubes, the AChR is specifically associated with multiple other proteins, including rapsyn, utrophin, $\beta$-dystroglycan, src-related kinases, and MuSK. The rapsyn dependence of some of these interactions indicates a role of rapsyn in selected associations and rules out general protein aggregation as a cause for the observed AChR protein complex. Several additional observations point toward the specificity of the protein interactions in the complex. First, neither syntrophin, another postsynaptic component of the dystrophin/utrophin glycoprotein complex, nor the transferrin receptor, a membrane protein, is associated with the AChR, although both are easily detected in muscle extracts. Second, the observed interactions occur with

$\leftarrow$

$B$, Quantitation of the AChR-MuSK interaction. MuSK immunoblots made from samples treated as described in $A$ were quantitated by densitometric scanning of films, and values of untreated cells were set to $100 \%$. Data represent mean \pm SD of at least five experiments. $C$, Quantitation of the AChR-utrophin and AChR- $\beta$-dystroglycan interaction. Immunoblots as shown in $A$ were quantitated by densitometric scanning, and values of agrin-treated control samples containing excess toxin $(+T)$ were set to $100 \%$; other values were calculated accordingly. Data represent mean \pm SD of at least six experiments. *Differs significantly from control ( $p<0.05$, by ANOVA followed by Bonferroni's $t$ test). 
different stoichiometries, ruling out general protein aggregation (Table 1). Finally, the proteins are dissociated from the AChR at different ionic strengths, with most of them stable in stringent conditions as described above.

\section{Tyrosine phosphorylation of MuSK and the AChR in rapsyn - /- myotubes}

Neural agrin causes tyrosine phosphorylation of two of the proteins that we observe in the AChR complex, MuSK and the AChR itself (Wallace et al., 1991; Glass et al., 1996). MuSK phosphorylation, of both the total pool and the AChR-associated fraction, occurs within minutes after agrin treatment and is paralleled by phosphorylation of the AChR $\beta$ subunit (Glass et al., 1996; Fuhrer et al., 1997). We examined the dependence of each of these phosphorylation events on rapsyn by determining their occurrence in rapsyn $-/-$ myotubes. To examine the phosphorylation of total MuSK, the myotubes were treated with neural or muscle agrin; MuSK was immunoprecipitated and examined by phosphotyrosine immunoblotting. The results obtained with rapsyn $-/-$ myotubes were similar to those seen in C2 and rapsyn wild-type myotubes because MuSK was phosphorylated within 15 min of treatment with neural but not muscle agrin (Fig. 7A), as shown previously by Apel et al. (1997). In addition, neural but not muscle agrin induced tyrosine phosphorylation of the pool of MuSK that is associated with the AChR (Fig. 7A). A statistical evaluation of several experiments showed no difference in the agrin-induced tyrosine phosphorylation of AChR-bound MuSK between wild-type and rapsyn-deficient myotubes (Fig. $7 C$ ). The lower relative intensity of the phosphorylated bands representing AChR-bound MuSK in rapsyn - / - and wild-type myotubes relative to C2 myotubes (Fuhrer et al., 1997) is presumably attributable to the lower proportion of myotubes as compared with myoblasts in the cultures, which explains the higher background in these cells. However, because agrin-induced phosphorylation of total and AChR-bound MuSK occurs indistinguishably and rapidly in both rapsyn $-/-$ and wild-type myotubes, we conclude from these experiments that rapsyn is not required for the tyrosine phosphorylation of either the total pool of MuSK or MuSK that is associated with the AChR.

In contrast, when phosphorylation of the AChR was examined, we saw a striking and significant difference between rapsyn -/and wild-type myotubes. Unlike in wild-type cells, the AChR $\beta$ subunit was not phosphorylated efficiently in agrin-treated rapsyn $-/-$ myotubes (Fig. $7 A, C$ ), as shown previously by Apel et al. (1997), although there was no difference in the amounts of $\alpha$-BTprecipitated AChRs and MuSK between the two cell lines (Fig. $7 B)$. In addition, we found that the weak constitutive tyrosine phosphorylation of the AChR $\beta$ subunit, which is observed independently of neural agrin in wild-type cells, is also reduced in rapsyn $-/-$ myotubes (Fig. $7 A, C$ ). These experiments show that rapsyn is essential for constitutive AChR phosphorylation, as well as the agrin-induced AChR phosphorylation, one of the early events in agrin signaling, but not for activation of total and AChR-bound MuSK.

\section{DISCUSSION}

In this study, we show that the AChR is associated with rapsyn and, to a lesser degree, utrophin and $\beta$-dystroglycan. Because it also interacts with src, fyn, and MuSK (Fuhrer and Hall, 1996; Fuhrer et al., 1997), the AChR has multiple specific associations with other proteins in myotubes. The rapsyn dependence of the utrophin and $\beta$-dystroglycan associations, together with the inter- action between these two proteins (James et al., 1996), suggests a complex containing at least four proteins-AChR, rapsyn, utrophin, and $\beta$-dystroglycan. Although we do not know whether this same complex also contains src-family kinases and MuSK, the occurrence of these associations in aneural myotubes shows that the AChRs are part of one or more complexes that are preformed before synaptogenesis; these complexes may thus play a role in the initiation and growth of the postsynaptic specialization.

\section{Molecular organization of the proteins associated with the AChR}

Of the proteins associated with the AChR, rapsyn is the most abundant. Rapsyn is known to be in close contact with the AChR and is present in a 1:1 stoichiometry with the AChR (Burden et al., 1983; LaRochelle and Froehner, 1987). Despite these and other long-standing indications that the two proteins are complexed, to our knowledge rapsyn has never been previously copurified or co-precipitated specifically with the AChR, probably because of the difficulty of extracting rapsyn from the insoluble cytoskeleton and its sensitivity to proteases (Froehner, 1991). For these and other reasons, our calculation on the stoichiometry of the AChR-rapsyn interaction is likely to be merely an indication of a more pronounced interaction occurring in vivo. One possibility, consistent with the 1:1 stoichiometry, is that all surface AChR molecules, both clustered and unclustered, are complexed to rapsyn in $\mathrm{C} 2$ myotubes. In support of this notion, both rapsyn and the AChR are diffusely distributed in mutant myotubes lacking AChR clusters (Gordon et al., 1993). Their association may occur initially intracellularly before surface transport, because both rapsyn and AChRs are associated with subpopulations of post-Golgi vesicles in Torpedo electrocytes (Bignami et al., 1998).

AChRs also interact in a rapsyn-dependent manner with $\beta$-dystroglycan and utrophin, two components of the dystrophin/utrophin glycoprotein complex. On the basis of the interaction between these two proteins (James et al., 1996), the $\beta$-dystroglycan could be bound to the AChR complex through utrophin. Utrophin, however, does not appear to be bound through $\beta$-dystroglycan, because under high salt conditions, $\beta$-dystroglycan is selectively lost from the complex. Our experiments are thus consistent with a novel model in which the AChR interacts directly with rapsyn, which is bound, either directly or through an intermediary protein, to utrophin, which is bound to $\beta$-dystroglycan (Fig. 8). We cannot exclude the possibility that $\beta$-dystroglycan is necessary for recruitment of other proteins (such as utrophin) during formation of this AChR protein complex. Once these proteins are bound, however, $\beta$-dystroglycan is no longer required for their continued association with the complex.

These findings define a role for rapsyn as the link between the $\mathrm{AChR}$ and the dystrophin/utrophin glycoprotein complex. At endplates, utrophin colocalizes precisely with AChRs at the crests of the postsynaptic folds (Colledge and Froehner, 1998a); our observed association of utrophin with the AChR complex may underlie this correct localization. By providing a cytoskeletal link early in development, utrophin may thus hold the AChR complex in its proper subcellular localization during postsynaptic differentiation. Indeed, in utrophin-deficient mice, the density of AChRs and the number of postsynaptic folds are reduced (Deconinck et al., 1997; Grady et al., 1997). Because these effects are subtle, however, other molecules and links are also important for 
A

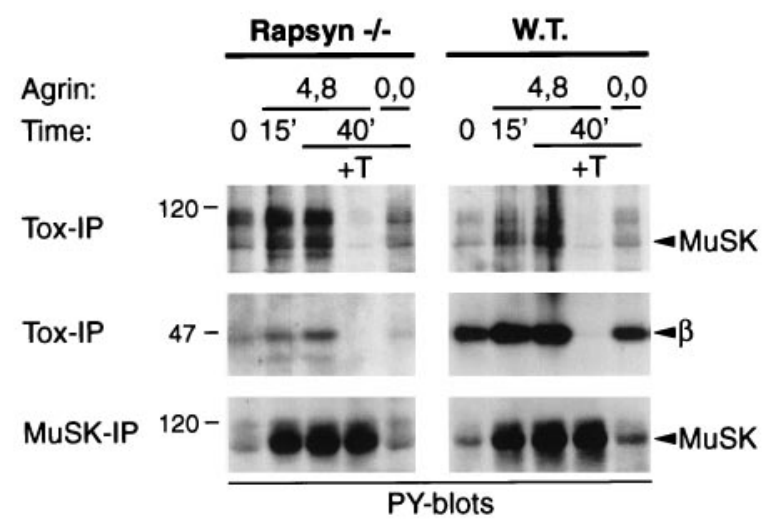

B

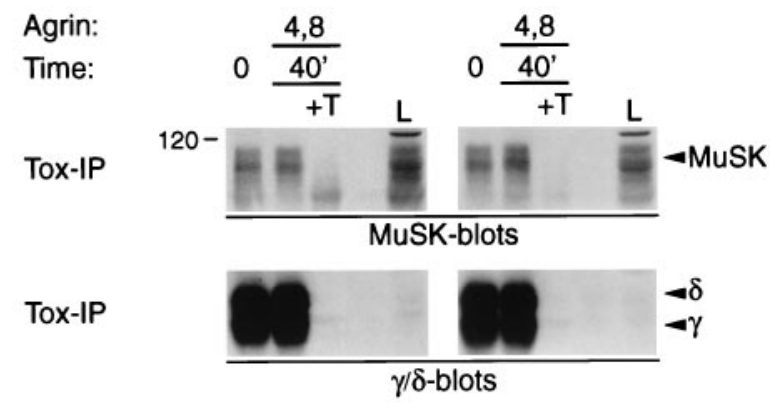

C
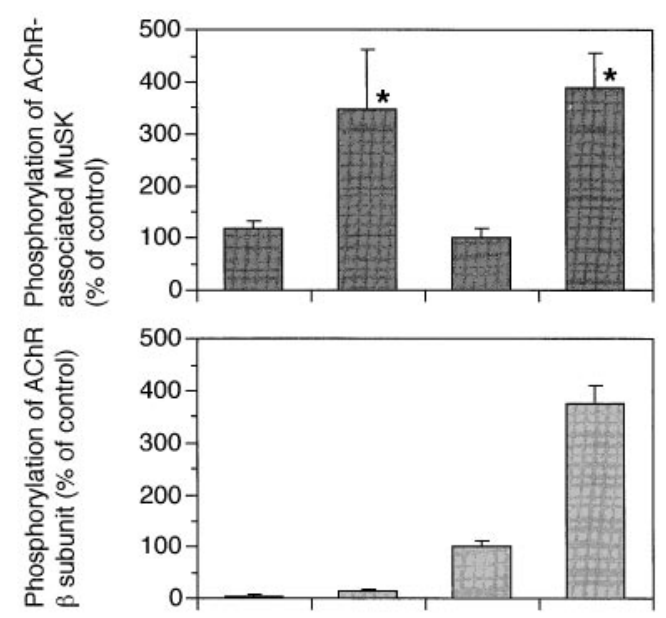

Agrin $(4,8)$ :

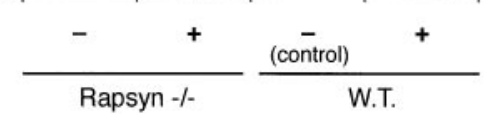

Figure 7. Agrin causes efficient tyrosine phosphorylation of AChRbound MuSK, but not of the AChR $\beta$ subunit, in rapsyn $-/-$ myotubes. Rapsyn -/- (11-7) and wild-type myotubes (12-10) were treated with 1 nM neural $(4,8)$ or muscle agrin $(0,0)$ as indicated. $A$, Lysates were split into two parts and incubated either with $\alpha$-BT-Sepharose beads (Tox-IP) to isolate AChRs or with MuSK antibodies and protein A-Sepharose beads to precipitate MuSK (MuSK-IP). Samples were analyzed by phosphotyrosine immunoblotting, and proteins were identified by their molecular weight and by stripping and reprobing the blots with the appropriate antisera (data not shown). Agrin causes phosphorylation of total and AChR-bound MuSK in both cell types. Phosphorylation of the AChR $\beta$ subunit is much stronger in the wild-type cells; a shorter exposure of the blots in the middle section reveals a strong agrin-induced signal in the wild-type cells and no signal at all in the mutant (data not shown). $B$, Levels of AChR-associated MuSK and AChRs isolated on toxin beads are equal in rapsyn $-/-$ and wild-type cells. AChRs were precipitated from lysates of mutant and wild-type cells, and samples were analyzed by immunoblotting with MuSK or AChR $\gamma / \delta$-specific antibodies. $L, 0.3 \%$ of postsynaptic differentiation and might compensate in the absence of utrophin.

In addition to linking the $\mathrm{AChR}$ to utrophin, rapsyn may also form a link to $\beta$-dystroglycan, based on its ability to cluster this protein in transfected fibroblasts and to interact with $\beta$-dystroglycan in biochemical assays (Apel et al., 1995; Cartaud et al., 1998). Thus, at the adult endplate, multiple rapsyndependent links between the AChR and the utrophin glycoprotein complex may exist to ensure maximal stabilization of AChRs.

We have shown previously that src and fyn are bound to the AChR (Fuhrer and Hall, 1996). As aggregated rapsyn is associated with an endogenous tyrosine kinase in transfected QT-6 fibroblasts (Qu et al., 1996), Apel et al. (1997) have suggested that src-related kinases bind to the AChR via rapsyn, but our experiments demonstrate that in myotubes these kinases interact with AChRs independently of rapsyn. Together, these results suggest that interactions between rapsyn and src-related kinases may also occur independently of the AChR. A similar situation occurs in the case of MuSK; we show that MuSK is associated independently of rapsyn with AChRs in untreated rapsyn -/- myotubes, whereas MuSK colocalizes with rapsyn in co-transfected fibroblasts (Gillespie et al., 1996; Apel et al., 1997). Thus, both MuSK and src-family kinases may have an AChR-independent interaction with rapsyn as well as a rapsyn-independent interaction with the AChR.

In summary, our work on the rapsyn $-/-$ myotubes shows that the AChR has two types of interactions with postsynaptic proteins: those that depend on rapsyn and those that do not. These findings modify and extend previously proposed rapsyn-mediated protein interactions that were largely based on protein colocalization in transfected QT-6 fibroblasts.

\section{Agrin signaling and $\mathrm{AChR}$-protein interactions}

As postsynaptic AChR clusters are induced by agrin during synaptogenesis, we were particularly interested in examining agrin's effects on protein associations with the AChR. To our surprise, agrin had no effect on most associations, except an increase in the case of MuSK (Fuhrer et al., 1997). This increase appears to be a biochemical correlate of the co-extensive clustering of both proteins, consistent with its absence in rapsyn -/myotubes. Furthermore, our results reveal two types of interactions of MuSK with the AChR: a rapsyn-independent interaction that occurs in the absence of agrin and a rapsyn-dependent interaction that is induced by agrin. The latter has an interesting parallel in transfected QT-6 cells, where coclustering of MuSK with AChRs depends on rapsyn (Gillespie et al., 1996; Apel et al., 1997). Provided that this represents biochemical interactions, QT-6 cells thus appear as a "short-cut" model for agrin- and rapsyn-mediated protein clustering. They allow protein aggrega-

$\leftarrow$

the total lysate was analyzed as a standard. $C$, Quantitation of tyrosine phosphorylation of AChR-bound MuSK and the AChR $\beta$ subunit. Immunoblots made from samples treated for $40 \mathrm{~min}$ as described in $A$ were quantitated by densitometric scanning of films. Short exposures of films were used that contained nonsaturated signals. The intensities were normalized for the amount of AChR-bound MuSK, as revealed in a toxin precipitation followed by a MuSK blot $(B)$. Values of untreated wild-type cells were set to $100 \%$, and other values were calculated accordingly. Data represent mean $\pm \mathrm{SD}$ of three experiments. ${ }^{*}$ Differ significantly from control ( $p<0.05$, by ANOVA followed by Bonferroni's $t$ test), but not from each other. 

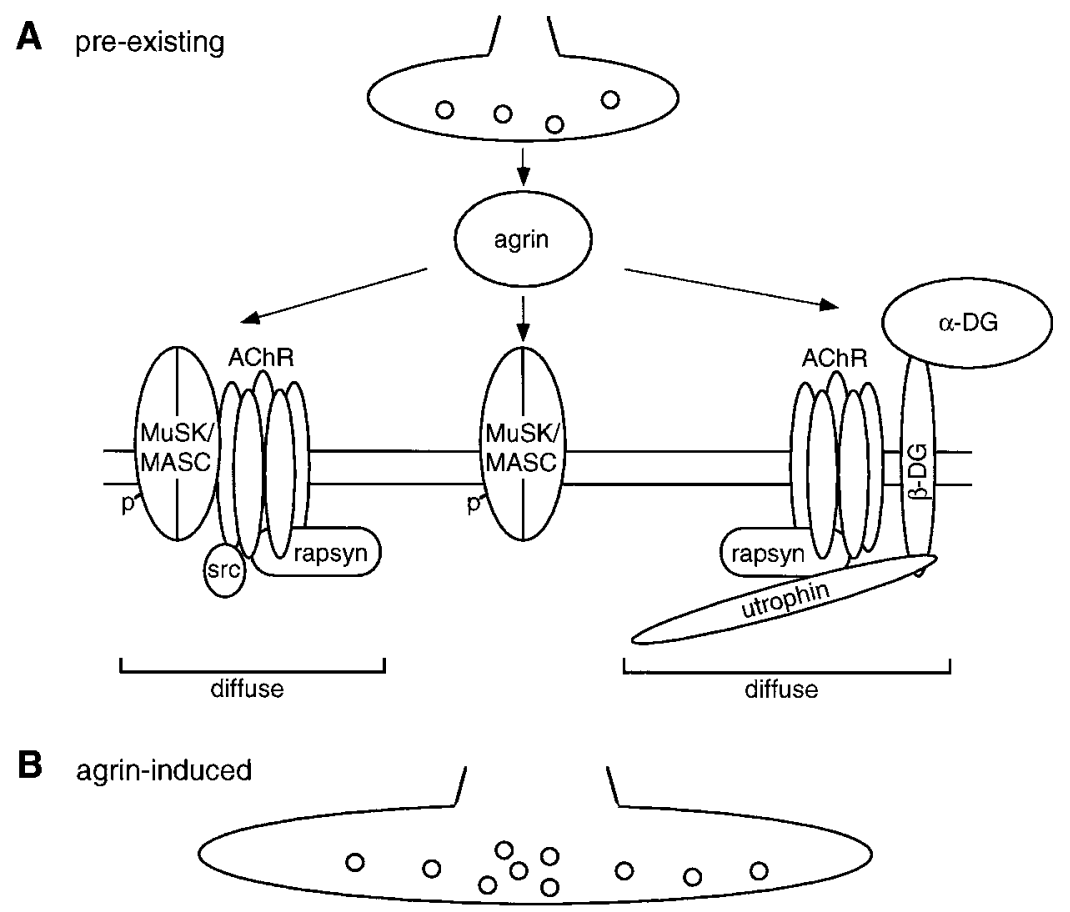

Figure 8. Model showing protein interactions with the $\mathrm{AChR}$ and steps in agrin-induced clustering of postsynaptic proteins. $A$, In the absence of nerves and neural agrin, diffusely distributed protein complexes exist in which rapsyn, $\beta$-dystroglycan, utrophin, MuSK, and src-related kinases interact with AChRs. Rapsyn mediates interaction of the AChR with utrophin and $\beta$-dystroglycan but not with MuSK and src-related kinases. We assume that all AChRs are complexed with rapsyn and that sites of nascent AChR clusters are marked by MuSK, perhaps in association with some AChR. B, Neural agrin leads to a link of the preexisting protein aggregates, using MuSK and rapsyn as effectors, thereby increasing the interaction between MuSK and AChRs in a rapsyn-dependent way. For more details, see Results. $p$, Phosphotyrosine; src, src-related kinases; $\beta$-DG, $\beta$-dystroglycan; $\alpha-D G, \alpha$-dystroglycan.

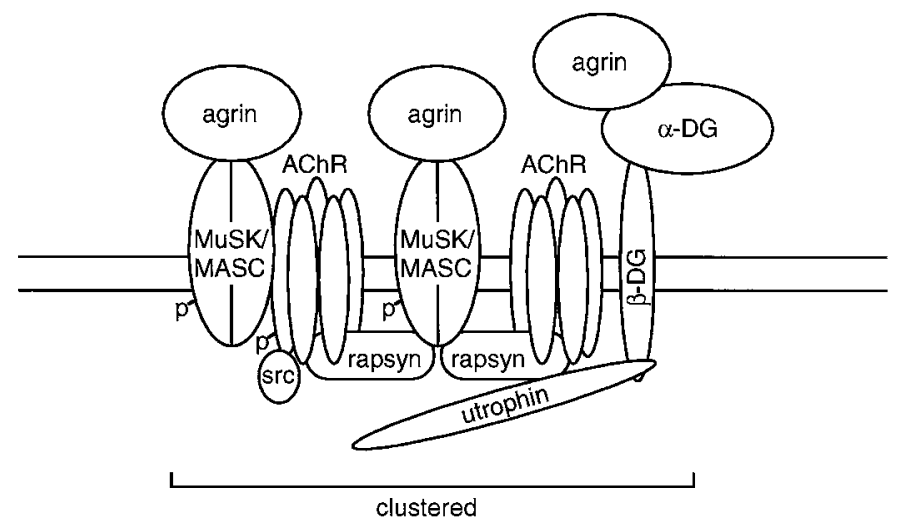

tions to occur that in myotubes are regulated in a more complex way by agrin, emphasizing the need to analyze AChR-protein interactions in myotubes.

Agrin causes tyrosine phosphorylation of the AChR $\beta$ subunit, which may result from a cascade in which agrin activates MuSK, leading to activation of AChR-bound src-related kinases, which phosphorylate the AChR (Fuhrer et al., 1997). In rapsyn -/myotubes, as in staurosporine-treated C2 myotubes (Fuhrer et al., 1997), agrin activates total and AChR-bound MuSK, but the AChR is not phosphorylated efficiently, suggesting that rapsyn is required for a step downstream of MuSK. Because src-related kinases bind to AChRs independently of rapsyn, presumably their activation or the activation of an unknown intermediary protein must require rapsyn. Rapsyn could thus hold AChRbound MuSK and src-related kinases in a conformation that allows activation of one kinase by the other, or it may itself interact with a kinase or other protein that mediates activation. In both scenarios, rapsyn appears as a scaffolding molecule involved in signal transduction. These roles may be mediated by the various protein domains of rapsyn (for review, see Colledge and Froehner, 1998b) and are reminiscent of ion channel-binding proteins at central synapses, e.g., PSD-95 at glutamatergic synapses (Kennedy, 1997; O’Brien et al., 1998).
Most of our observed AChR-protein interactions are unchanged by agrin, implying that they can occur with diffusely distributed AChRs. We show this explicitly for src-related kinases and a fraction of MuSK, which interact with AChRs in rapsynnegative myotubes lacking spontaneous AChR clusters. For rapsyn, in particular, its interaction with unclustered AChRs is a novel idea and contrasts with earlier models that postulated that rapsyn forms a scaffold for the recruitment of AChRs and other proteins (W. P. Phillips et al., 1991). Our observations rather suggest that conformational changes and/or additional proteins are involved in docking diff usely distributed pre-existing AChRrapsyn complexes at sites of nascent AChR clusters. Such sites may initially be marked by MuSK, perhaps in association with some of the AChRs, consistent with the localization of MuSK at mutant endplates in rapsyn -/- mice (Fig. 8) (Apel et al., 1997).

These observations raise the new concept that the AChR, while still diffusely distributed, serves as a scaffold to which kinases as well as anchoring proteins are attached. Indeed, these preassembled complexes of AChRs and other proteins may form the functional building blocks for agrin-induced AChR clusters. Several observations support this notion indirectly. For example, expression of a chimeric membrane-bound, activated MuSK kinase domain throughout myotubes causes phosphorylation but 
not clustering of AChRs, consistent with the assumption that MuSK's ectodomain and its association with AChRs are crucial for cluster formation (Glass et al., 1997). Furthermore, in AChR $\epsilon$ subunit-deficient recombinant mice, many postsynaptic components are gradually lost along with AChRs during the short life span of these mice, demonstrating a crucial stabilizing effect of AChRs on other proteins at endplates (Witzemann et al., 1996; Missias et al., 1997).

Our data thus imply that neural agrin acts to attach preassembled, diffusely distributed AChR complexes to the sites of nascent clusters (marked by MuSK) underlying nerve terminals (Fig. 8). This attachment appears to occur by direct or indirect binding of the rapsyn in the AChR-protein complexes to MuSK, leading to the observed increase in the AChR-MuSK interaction. The clustered complex containing proteins required for synaptogenesis (agrin, MuSK, rapsyn, and AChRs) then acts as the scaffold that supports the growth and stabilization of the cluster and the further elaboration of the postsynaptic membrane. A crucial aim of future experiments will be to describe more fully the molecular interactions and the proteins that underlie these events.

\section{REFERENCES}

Apel ED, Merlie JP (1995) Assembly of the postsynaptic apparatus. Curr Opin Neurobiol 5:62-67.

Apel ED, Roberds SL, Campbell KP, Merlie JP (1995) Rapsyn may function as a link between the acetylcholine receptor and the agrinbinding dystrophin-associated glycoprotein complex. Neuron 15:115-126.

Apel ED, Glass DJ, Moscoso LM, Yancopoulos GD, Sanes JR (1997) Rapsyn is required for MuSK signaling and recruits synaptic components to a MuSK-containing scaffold. Neuron 18:623-635.

Bezakova G, Bloch RJ (1998) The zinc finger domain of the 43-kDa receptor-associated protein, rapsyn: role in acetylcholine receptor clustering. Mol Cell Neurosci 11:274-288.

Bignami F, Camus G, Marchand S, Bailly L, Stetzkowski-Marden F, Cartaud J (1998) Targeting of acetylcholine receptor and 43kDa rapsyn to the postsynaptic membrane in Torpedo marmorata electrocyte. J Physiol (Paris) 92:177-181.

Buckel A, James E, Leslie J, Biewenga J, Beeson D, Vincent A (1998) Evidence for an association between human acetylcholine receptor and rapsyn. Ann NY Acad Sci 841:14-16.

Burden SJ, DePalma RL, Gottesman GS (1983) Crosslinking of proteins in acetylcholine receptor-rich membranes: association between the beta-subunit and the $43 \mathrm{kD}$ subsynaptic protein. Cell 35:687-692.

Cartaud A, Coutant S, Petrucci TC, Cartaud J (1998) Evidence for in situ and in vitro association between $\beta$-dystroglycan and the subsynaptic 43K rapsyn protein. J Biol Chem 273:11321-11326.

Cohen I, Rimer M, Lomo T, McMahan UJ (1997) Agrin-induced postsynaptic-like apparatus in skeletal muscle fibers in vivo. Mol Cell Neurosci 9:237-253.

Colledge M, Froehner SC (1998a) Signals mediating ion channel clustering at the neuromuscular junction. Curr Opin Neurobiol 8:357-363.

Colledge M, Froehner SC (1998b) To muster a cluster: anchoring neurotransmitter receptors at synapses. Proc Natl Acad Sci USA 95:3341-3343.

DeChiara TM, Bowen DC, Valenzuela DM, Simmons MV, Poueymirou WT, Thomas S, Kinetz E, Compton DL, Rojas E, Park JS, Smith C, DiStefano PS, Glass DJ, Burden SJ, Yancopoulos GD (1996) The receptor tyrosine kinase MuSK is required for neuromuscular junction formation in vivo. Cell 85:501-512.

Deconinck AE, Potter AC, Tingsley JM, Wood SJ, Vater R, Young C, Metzinger L, Vincent A, Slater CR, Davies KE (1997) Postsynaptic abnormalities at the neuromuscular junctions of utrophin-deficient mice. J Cell Biol 136:883-894.

Ferns M, Hoch W, Campanelli JT, Rupp F, Hall ZW, Scheller RH (1992) RNA splicing regulates agrin-mediated acetylcholine receptor clustering activity on cultured myotubes. Neuron 8:1079-1086.

Ferns MJ, Campanelli JT, Hoch W, Scheller RH, Hall Z (1993) The ability of agrin to cluster AChRs depends on alternative splicing and on cell surface proteoglycans. Neuron 11:491-502.
Ferns M, Deiner M, Hall Z (1996) Agrin-induced acetylcholine receptor clustering in mammalian muscle requires tyrosine phosphorylation. J Cell Biol 132:937-944.

Forsayeth JR, Garcia PD (1994) Adenovirus-mediated transfection of cultured cells. Biotechniques 17:354-358.

Froehner SC (1991) The submembrane machinery for nicotinic acetylcholine receptor clustering. J Cell Biol 114:1-7.

Froehner SC, Murnane AA, Tobler M, Peng HB, Sealock R (1987) A postsynaptic $\operatorname{Mr} 58,000(58 \mathrm{~K})$ protein concentrated at acetylcholine receptor-rich sites in Torpedo electroplaques and skeletal muscle. J Cell Biol 104:1633-1646.

Froehner SC, Luetje CW, Scotland PB, Patrick J (1990) The postsynaptic $43 \mathrm{~K}$ protein clusters muscle nicotinic acetylcholine receptors in Xenopus oocytes. Neuron 5:403-410.

Fuhrer C, Hall ZW (1996) Functional interaction of src family kinases with the acetylcholine receptor in $\mathrm{C} 2$ myotubes. J Biol Chem 271:32474-32481.

Fuhrer C, Sugiyama JE, Taylor RG, Hall ZW (1997) Association of muscle-specific kinase MuSK with the acetylcholine receptor in mammalian muscle. EMBO J 16:4951-4960.

Gautam M, Noakes PG, Mudd J, Nichol M, Chu GC, Sanes JR, Merlie JP (1995) Failure of postsynaptic specialization to develop at neuromuscular junctions of rapsyn-deficient mice. Nature 377:232-236.

Gautam M, Noakes PG, Moscoso L, Rupp F, Scheller RH, Merlie JP, Sanes JR (1996) Defective neuromuscular synaptogenesis in agrindeficient mice. Cell 85:525-535.

Gillespie SKH, Balasubramanian S, Fung ET, Huganir RL (1996) Rapsyn clusters and activates the synapse-specific receptor kinase MuSK. Neuron 16:953-962.

Glass DJ, Bowen DC, Stitt TN, Radziejewski C, Bruno J, Ryan TE, Gies DR, Shah S, Mattsson K, Burden SJ, DiStefano PS, Valenzuela DM, DeChiara TM, Yancopoulos GD (1996) Agrin acts via a MuSK receptor complex. Cell 85:513-523.

Glass DJ, Apel ED, Shah S, Bowen DC, DeChiara TM, Stitt TN, Sanes JR, Yancopoulos GD (1997) Kinase domain of the muscle-specific receptor tyrosine kinase (MuSK) is sufficient for phosphorylation but not clustering of acetylcholine receptors: required role for the MuSK ectodomain? Proc Natl Acad Sci USA 94:8848-8853.

Gordon H, Lupa M, Bowen D, Hall Z (1993) A muscle cell variant defective in glycosaminoglycan biosynthesis forms nerve-induced but not spontaneous clusters of the acetylcholine receptor and the $43 \mathrm{kDa}$ protein. J Neurosci 13:586-595.

Grady RM, Merlie JP, Sanes JR (1997) Subtle neuromuscular defects in utrophin-deficient mice. J Cell Biol 136:871-882.

Gu Y, Hall ZW (1988) Characterization of acetylcholine receptor subunits in developing and in denervated mammalian muscle. J Biol Chem 263:12878-12885.

Hall ZW, Sanes JR (1993) Synaptic structure and development: the neuromuscular junction. Neuron [Suppl] 10:99-121.

Ibraghimov-Beskrovnaya O, Ervasti JM, Leveille CJ, Slaughter CA, Sernett SW, Campbell KP (1992) Primary structure of dystrophinassociated glycoproteins linking dystrophin to the extracellular matrix. Nature 355:696-702.

James M, Nguyen TM, Wise CJ, Jones GE, Morris GE (1996) Utrophindystroglycan complex in membranes of adherent cultured cells. Cell Motil Cytoskeleton 33:163-174.

Jat PS, Noble MD, Ataliotis P, Tanaka Y, Yannoutsos N, Larsen L, Kioussis D (1991) Direct derivation of conditionally immortal cell lines from an $\mathrm{H}-2 \mathrm{~Kb}$-tsA58 transgenic mouse. Proc Natl Acad Sci USA 88:5096-5100.

Jennings CGB, Dyer SM, Burden SJ (1993) Muscle-specific trk-related receptor with a kringle domain defines a distinct class of receptor tyrosine kinases. Proc Natl Acad Sci USA 90:2895-2899.

Kennedy MB (1997) The postsynaptic density at glutamatergic synapses. Trends Neurosci 20:264-268.

LaRochelle WJ, Froehner SC (1986) Determination of the tissue distributions and relative concentrations of the postsynaptic $43 \mathrm{kDa}$ protein and the acetylcholine receptor in Torpedo. J Biol Chem 261:5270-5274.

LaRochelle WJ, Froehner SC (1987) Comparison of the postsynaptic 43 $\mathrm{kDa}$ protein from muscle cells that differ in acetylcholine receptor clustering activity. J Biol Chem 262:8190-8195.

Lesley J, Schulte R, Woods J (1989) Modulation of transferrin receptor expression and function by anti-transferrin receptor antibodies and antibody fragments. Exp Cell Res 182:215-233. 
McMahan UJ (1990) The agrin hypothesis. Cold Spring Harbor Symp Quant Biol 55:407-418.

Megeath LJ, Fallon JR (1998) Intracellular calcium regulates agrininduced acetylcholine receptor clustering. J Neurosci 18:672-678.

Meier T, Perez GM, Wallace BG (1995) Immobilization of nicotinic acetylcholine receptors in mouse $\mathrm{C} 2$ myotubes by agrin-induced protein tyrosine phosphorylation. J Cell Biol 131:441-451.

Meier T, Hauser DM, Chiquet M, Landmann L, Ruegg MA, Brenner HR (1997) Neural agrin induces ectopic postsynaptic specializations in innervated muscle fibers. J Neurosci 17:6534-6544.

Meyer G, Wallace BG (1998) Recruitment of a nicotinic acetylcholine receptor mutant lacking cytoplasmic tyrosine residues in its $\beta$ subunit into agrin-induced aggregates. Mol Cell Neurosci 11:324-333.

Missias AC, Mudd J, Cunningham JM, Steinbach JH, Merlie JP, Sanes JR (1997) Deficient development and maintenance of postsynaptic specializations in mutant mice lacking an "adult" acetylcholine receptor subunit. Development 124:5075-5086.

Mitsui T, Kawai H, Kawajiri M, Kunishige M, Aki K, Saito S (1996) Induction of dystrophin-associated proteins together with nicotinic acetylcholine receptors by denervation in the absence of dystrophin in skeletal muscle of $\mathrm{mdx}$ mice. Biochem Biophys Res Commun 224:802-807.

Morgan JE, Beauchamp JR, Pagel CN, Peckham M, Ataliotis P, Jat PS, Noble MD, Farmer K, Partridge TA (1994) Myogenic cell lines derived from transgenic mice carrying a thermolabile T-antigen: a model system for the derivation of tissue-specific and mutation-specific cell lines. Dev Biol 162:486-498.

O’Brien RJ, Lau L-F, Huganir RL (1998) Molecular mechanisms of glutamate receptor clustering at excitatory synapses. Curr Opin Neurobiol 8:364-369.

Ohlendieck K, Ervasti JM, Matsumura K, Kahl SD, Leveille CJ, Campbell KP (1991) Dystrophin-related protein is localized to neuromuscular junctions of adult skeletal muscle. Neuron 7:499-508.

Peters MF, Kramarcy NR, Sealock R, Froehner SC (1994) $\beta 2$-syntrophin: localization at the neuromuscular junction in skeletal muscle. NeuroReport 5:1577-1580.
Phillips WD, Maimone MM, Merlie JP (1991) Mutagenesis of the 43-kD postsynaptic protein defines domains involved in plasma membrane targeting and AChR clustering. J Cell Biol 115:1713-1723.

Phillips WP, Kopta C, Blount P, Gardner PD, Steinbach JH, Merlie JP (1991) ACh receptor-rich membrane domains organized in fibroblasts by recombinant 43-kilodalton protein. Science 251:568-570.

Qu Z, Apel ED, Doherty CA, Hoffman PW, Merlie JP, Huganir RL (1996) The synapse-associated protein rapsyn regulates tyrosine phosphorylation of proteins colocalized at nicotinic acetylcholine receptor clusters. Mol Cell Neurosci 8:171-184.

Reist NE, Werle MJ, McMahan UJ (1992) Agrin released by motor neurons induces the aggregation of AChRs at neuromuscular junctions. Neuron 8:865-868.

Swope SL, Huganir RL (1993) Molecular cloning of two abundant protein tyrosine kinases in torpedo electric organ that associate with the acetylcholine receptor. J Biol Chem 268:25152-25161.

Swope SL, Huganir RL (1994) Binding of nicotinic acetylcholine receptor to $\mathrm{SH} 2$ domains of fyn and fyk protein tyrosine kinases. J Biol Chem 269:29817-29824.

Unwin N (1993) Nicotinic acetylcholine receptor at 9 A resolution. J Mol Biol 229:1101-1124.

Valenzuela DM, Stitt TN, DiStefano PS, Rojas E, Mattsson K, Compton DL, Nunez L, Park JS, Stark JL, Gies DR, Thomas S, Le Beau MM, Fernald AA, Copeland NG, Jenkins NA, Burden SJ, Glass DJ, Yancopoulos GD (1995) Receptor tyrosine kinase specific for the skeletal muscle lineage: expression in embryonic muscle, at the neuromuscular junction, and after injury. Neuron 15:573-584.

Wallace BG (1989) Agrin-induced specializations contain cytoplasmic, membrane, and extracellular matrix-associated components of the postsynaptic apparatus. J Neurosci 9:1294-1302.

Wallace BG, Qu Z, Huganir RL (1991) Agrin induces phosphorylation of the nicotinic acetylcholine receptor. Neuron 6:869-878.

Witzemann V, Schwarz H, Koenen M, Berberich C, Villarroel A, Wernig A, Brenner HR, Sakmann B (1996) Acetylcholine receptor epsilonsubunit deletion causes muscle weakness and atrophy in juvenile and adult mice. Proc Natl Acad Sci USA 93:13286-13291. 